\title{
VARIATION IN AVIAN DIVERSITY IN RELATION TO PLANT SPECIES IN URBAN PARKS OF AYDIN, TURKEY
}

\author{
ASIK, Y. $.^{*}-\mathrm{KARA}, \mathrm{B} .{ }^{2}$ \\ ${ }^{I}$ Department of Landscape Architecture, Burdur Mehmet Akif Ersoy University, 15030 Burdur, \\ Republic of Turkey \\ ${ }^{2}$ Department of Landscape Architecture, Aydin Adnan Menderes University, 09970 Aydin, \\ Republic of Turkey \\ *Corresponding author \\ e-mail: yasik@mehmetakif.edu.tr; phone: +90-248-213-2782 \\ (Received 13 ${ }^{\text {th }}$ Jan 2021; accepted $18^{\text {th }}$ Mar 2021)
}

\begin{abstract}
Among wildlife species, birds are important indicators of biodiversity and habitat quality in urban ecosystems. Parks, which are among the important components of urban ecosystems, are home to many bird species with their diversity of plant species. Due to this aspect, parks make significant contributions to increase bird diversity. The bird species were observed with the naked eye and using an Olympus 10x50 DPS I brand binocular. Bird observations were performed on sunny days without rain and excessive wind in the mornings (07.00-09.00 a.m./2 h after sunrise) and evenings. Sixteen bird species observed in urban parks of Aydin comprised 11 native, 11 resident and 9 insectivorous species. The Eurasian Collared-Dove (Streptopelia decaocto Frivaldszky), Eurasian Jackdaw (Corvus monedula L.), Hooded Crow (Corvus cornix L.), Great Tit (Parus major L.), and House Sparrow (Passer domesticus L.) were the most frequently observed bird species in all parks. The Australian Pine (Casuarina equisetifolia L.) attracted the highest number of bird species with 12 species, followed by the Turkish Pine (Pinus brutia Ten.) with 11 species. A significant variance was found between plant species and avian diversity.
\end{abstract}

Keywords: biodiversity, bird richness, habitat, landscape ecology, species distribution

\section{Introduction}

Many cities in the world are home to many wildlife species since they have unlimited opportunities that meet vital needs such as food, water, shelter, and nesting (Pacheco and Vasconcelos, 2007; Baldock et al., 2015; Goertzen and Suhling, 2015; Kowarik and von der Lippe, 2018). Among these wildlife species, birds take an important place since they are common and easily observable (Suarez-Rubio et al., 2016; Bradbury, 2019; Moss and Martin, 2019) Cities are considered to be ecosystems with the potential to support various bird communities (Shochat et al., 2010). Of all bird species in the world, 20\% live in cities (Aronson et al., 2014). Urban bird communities are divided into five groups based on their relationships with the urban ecosystem: urban avoiders, urban exploiters, urban adapters, residents, and migrants (Blair, 1996).

Parks have a high diversity of vegetation since they are usually the most heterogeneous green areas in the urban ecosystem (Gilbert, 1989; Hadidian et al., 1997; Rottenborn, 1999).

Because of the high diversity of vegetation, parks are among the important habitats for birds in cities (Jokimäki, 1999). Parks make significant contributions to the conservation of bird diversity and richness (Cornelis and Hermy, 2004; Khera et al., 2009; Carvajal-Castro et al., 2019). 
Birds are important indicators of habitat quality (Fontana et al., 2011a). The bird life in parks also increases the life quality of users. Park visitors are in search of a wildlife atmosphere, which differs from their work environments (Baines, 2000). Urban birds and their diversity make up a significant factor regarding how people can experience urban nature. Since communicating with birds means communicating with nature, it improves the physical, mental, and emotional health of urban dwellers (Moss and Martin, 2019).

All birds have different habitat requirements. However, they need food which they can feed on and feed their offspring with, and trees as well as shrubs where they can shelter and build a nest (Bradbury, 2019).

Bird communities in cities largely vary depending on the type and structure of vegetation (Sewell and Catterall, 1998; Fernández-Juricic and Jokimäki, 2001; White et al., 2005; Villegas and Garitano-Zavala, 2010). It was found that vegetation was positively associated with bird species richness. The more species of trees and shrubs there are that produce seeds and fruits and bloom at different times, the more bird species parks attract (Bauer, 2012; Bradbury, 2019). Trees are considered to be one of the most important plant components that increase bird species richness and diversity in parks since they provide opportunities for nutrition, shelter, and nesting (Fontana et al., 2011b; Aronson et al., 2014; Beninde et al., 2015). The shrub vegetation in parks is considered an important microhabitat since it decreases the problems to be caused by people by reducing their visibility, gives birds a chance to escape, and reduces the risk of hunting (Martín and López, 1995; Kramer and Bonenfant, 1997; Yang et al., 2015).

The most important problem related to wildlife in parks is that most plant species are exotic (Taylor, 2015). Most of the exotic species are less important for native bird species since they have a low food supply. Most of the plants in wildlife-friendly parks comprise native species (Bradbury, 2019).

The most important way for parks to increase the value of bird habitat is that plants are in layers in the form of trees, shrubs, and groundcovers as in nature (Bauer, 2012). This diversity of vegetation layers increases nutritional, sheltering, and nesting opportunities for different bird species (Marzluff and Ewing, 2001; Tews et al., 2004).

Information on the patterns of urban bird populations and communities appeared in the 1970s (Emlen, 1974). Most of the studies on urban birds addressed the key issues of abundance and distribution (Shochat et al., 2010). A lot of studies were conducted on birds within the context of urban ecology (Lepczyk and Warren, 2012; Shwartz et al., 2013; Gil and Brumm, 2014). In very few studies, the importance of vegetation structure for bird communities was examined (Keller et al., 2003; Macgregor-Fors and Schondube, 2011). However, variations in the distribution of bird species in cities depending on the vegetation profile remains unclear. There are no studies examining the relationship between bird diversity and plant species in the parks in Turkey, despite its potential significance. The study hypothesis is that in urban parks of Aydin, depending on the vegetation profile, the diversity of birds would change.

In the study, 1-the vegetation structure in the parks, which made up the study area, was revealed and 2- to what extent this vegetation affected the variation in bird species was investigated. 


\section{Materials and Methods}

\section{Study area}

The study area was the Pinarbasi Recreation Area, Aytepe Recreation Area, Nevzat BICER Park, and Ismet SEZGIN Park in Aydin city (Figure 1). While the population of Aydin city in 2019 was 293,816 (TUIK, 2020), its altitude is 59 m, and its surface area is $631 \mathrm{~km}^{2}$. The Mediterranean climate prevails in the city. The mean annual temperature is $17.8{ }^{\circ} \mathrm{C}$, and the mean annual amount of precipitation is $646 \mathrm{~mm}$. The Pinarbasi Recreation Area is $32,195.63 \mathrm{~m}^{2}$, the Aytepe Recreation Area is $15,828.97 \mathrm{~m}^{2}$, Nevzat BICER Park is $14,663.16 \mathrm{~m}^{2}$, and Ismet SEZGIN Park is $8,043.85 \mathrm{~m}^{2}$. The Pinarbasi Recreation Area and Aytepe Recreation Area are on the urban fringe, and Nevzat BICER Park and Ismet SEZGIN Park are in the city center.

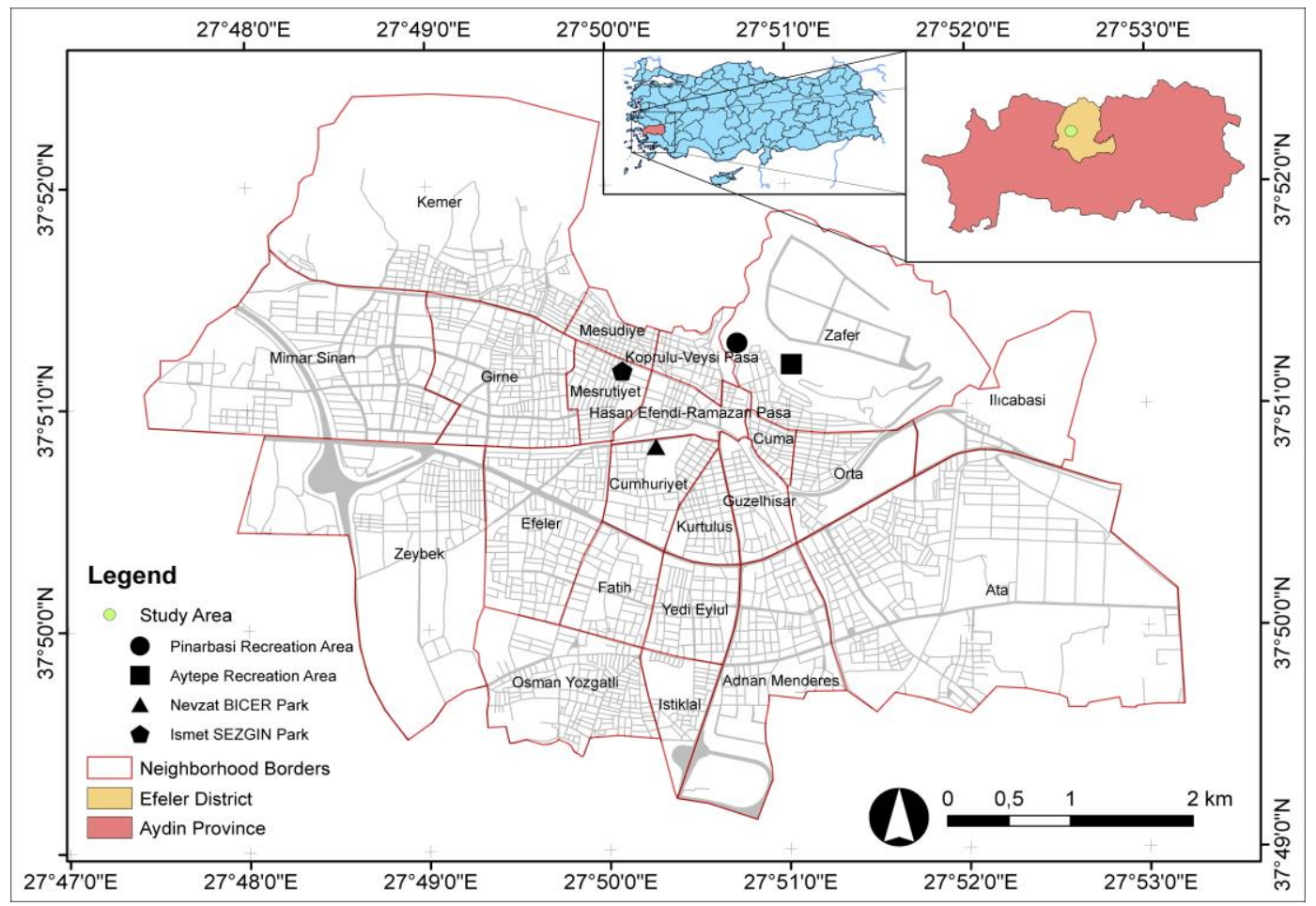

Figure 1. Study area

\section{Observation tools}

The bird species were observed with the naked eye and using an Olympus 10x50 DPS I brand binocular.

\section{Bird data collection}

Bird observations were performed on sunny days without rain and excessive wind, in the mornings (07.00-09.00 a.m./2 h after sunrise) and evenings (17.00-19.00 p.m./ $2 \mathrm{~h}$ before dark) (Meles and Bogale, 2018) during which bird activity was maximum, in the non-breeding season of 2019 between 16-26 September (Threlfall et al., 2016; Kale et al., 2018; Carvajal-Castro et al., 2019; Mao et al., 2019; Vaccaro et al., 2019). The nonbreeding season is defined as the period during which wintering birds are likely to be 
present and the resident bird species are unlikely to breed (Braden et al., 2007). Bird data were collected by using a standard five-minute point-count method (Heezik et al., 2010; Yang et al., 2015; van Camacho-Cervantes et al., 2018; Wolff et al., 2018; Filloy et al., 2019; Vaccaro et al., 2019). All birds heard or seen (McCurdy, 2016; Threlfall et al., 2016; Callaghan et al., 2018; Filloy et al., 2019; Vaccaro et al., 2019) within a radius of $25 \mathrm{~m}$ from each observation point (Shanahan et al., 2011; Yang et al., 2015) were observed. The observations were performed by walking on the line between observation points (Chong et al., 2014; Yang et al., 2015; Kale et al., 2018). The observations were performed at 67 points, including 33 points in the Pinarbasi Recreation Area, 19 points in the Aytepe Recreation Area, 9 points in Nevzat BICER Park, and 6 points in Ismet SEZGIN Park (Figure 2). In four parks which made up the study area, 32 hours of observations were performed in 16 different time periods in 8 days. The observations were performed by two observers trained on visual and auditory bird identification (Verner and Milne, 1989).

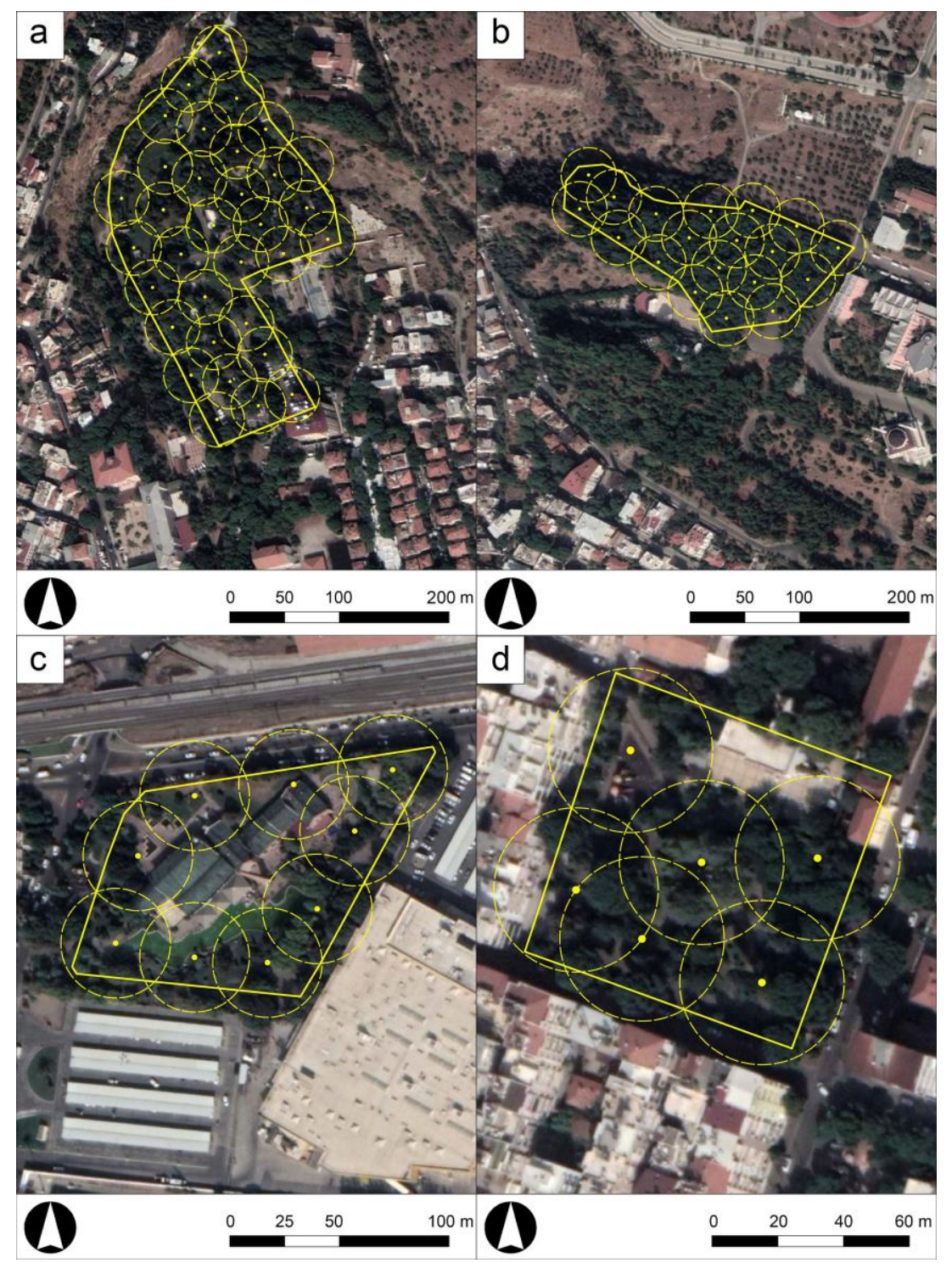

Figure 2. Observation points (a) Pinarbasi Recreation Area, (b) Aytepe Recreation Area, (c) Nevzat BICER Park, (d) Ismet SEZGIN Park 


\section{Data analysis}

The feature data used in bird identification were collected from published sources (Heinzel et al., 1995) and online bird databases (Bird Life International, 2011; eBird, 2012; Rodewald, 2015; The Cornell Lab, 2017). The published sources (Karamanoglu, 1976; Mamıkoglu, 2010; Akkemik, 2018) were used in the identification of plants. The observation points were created on a Quickbird satellite image using ArcMap 10.7 software. The birds were classified according to their scientific names and taxonomic structure (Kirwan et al., 2008; AOU, 2009; Gill and Donsker, 2020; TRAKUS, 2020), native and exotic status, residency status, urban associations (Howell and Webb, 1995), and guilds.

\section{Statistical analysis}

The statistical software package SPSS 25.0 (IBM Corp. Released 2017. IBM SPSS Statistics for Windows, Version 25.0. Armonk, NY: IBM Corp.) was used to analyze statistically the study data. First, the data's normality assumption was tested. It was determined that the data not met the normality assumption. Therefore, it was applied non-parametric tests to the data. Using the Mann-Whitney $U$ test, the connection between binary independent categorical variables was analyzed and the connection between triple independent categorical variables was analyzed using the Kruskal Wallis $\mathrm{H}$ test. Statistical analysis included only plants on which birds were observed and the birds on which they were observed, not all plant species and bird species. Plant heights for statistical analysis were classified as short, medium, high for $<10 \mathrm{~m}, 10-20 \mathrm{~m}$ and $>20 \mathrm{~m}$, respectively. No individual measurements have been taken because all the plant species in the study area are adults. The average plant height was calculated, taking advantage of published sources used in data analysis section.

\section{Results}

\section{Plant species and bird species in the study area}

While the highest number of native tree species (15 species) was present in the Pinarbasi Recreation Area, the lowest number of native tree species (7 species) was present in the Aytepe Recreation Area and Nevzat BICER Park. While the highest number of exotic tree species (24 species) was present in Nevzat BICER Park, the lowest number of exotic tree species (1 species) was present in the Aytepe Recreation Area. The highest number of native shrub species (6 species) was present in the Pinarbasi Recreation Area and Nevzat BICER Park. However, the lowest number of native shrub species (2 species) was present in the Aytepe Recreation Area. The highest number of exotic shrub species (21 species) was present in Ismet SEZGIN Park, and the lowest number of exotic shrub species (4 species) was present in the Aytepe Recreation Area (Table 1).

In the observations performed in four parks in Aydin city, 16 bird species from 9 families were observed. While the highest number of bird species (14 species) was observed in the Pinarbasi Recreation Area, the lowest number of bird species ( 8 species) was observed in Nevzat BICER and Ismet SEZGIN Parks. The observed birds comprised 11 native, 5 exotic, 11 resident, 5 migrant, 14 urban adapter (5 exotic, 9 native) and 2 urban exploiter (native species) species. While 9 of the observed bird 
species were insectivorous species, 6 and 1 of them were omnivorous and granivorous species, respectively (Table 2).

Table 1. Native and exotic plant species in the study area

\begin{tabular}{|c|c|c|c|c|c|c|}
\hline \multirow[b]{2}{*}{$\begin{array}{l}\text { Plant } \\
\text { Species }\end{array}$} & \multirow[b]{2}{*}{$\begin{array}{l}\text { Species and } \\
\text { Frequency }\end{array}$} & \multirow[b]{2}{*}{$\begin{array}{l}\text { Native (N) or } \\
\text { Exotic (E) }\end{array}$} & \multicolumn{4}{|c|}{ Urban Parks } \\
\hline & & & $\begin{array}{c}\text { Pinarbasi } \\
\text { Recreation Area }\end{array}$ & $\begin{array}{c}\text { Aytepe } \\
\text { Recreation } \\
\text { Area }\end{array}$ & $\begin{array}{c}\text { Nevzat } \\
\text { BICER Park }\end{array}$ & $\begin{array}{c}\text { Ismet } \\
\text { SEZGIN Park }\end{array}$ \\
\hline \multirow{4}{*}{ Tree } & \multirow{2}{*}{ Species } & $\mathrm{N}$ & 15 & 7 & 7 & 11 \\
\hline & & E & 21 & 1 & 24 & 13 \\
\hline & \multirow{2}{*}{ Frequency } & $\mathrm{N}$ & 246 & 616 & 40 & 92 \\
\hline & & $\mathrm{E}$ & 269 & 3 & 199 & 51 \\
\hline \multirow{4}{*}{ Shrub } & \multirow{2}{*}{ Species } & $\mathrm{N}$ & 6 & 2 & 6 & 4 \\
\hline & & E & 11 & 4 & 15 & 21 \\
\hline & \multirow{2}{*}{ Frequency } & $\mathrm{N}$ & 452 & 61 & 32 & 64 \\
\hline & & E & 202 & 1078 & 385 & 724 \\
\hline
\end{tabular}

Table 2. Bird species observed in the study area

\begin{tabular}{|c|c|c|c|c|c|c|c|}
\hline \multirow{2}{*}{ Latin Name } & \multirow{2}{*}{ Common Name } & \multirow{2}{*}{ Family } & \multirow{2}{*}{ Status* } & \multicolumn{4}{|c|}{ Urban Parks** } \\
\hline & & & & PRA & ARA & NBP & ISP \\
\hline $\begin{array}{l}\text { Streptopelia decaocto } \\
\text { Frivaldszky }\end{array}$ & $\begin{array}{c}\text { Eurasian } \\
\text { Collared-Dove }\end{array}$ & Columbidae & N-R-UA-G & $\bullet$ & • & $\bullet$ & $\bullet$ \\
\hline Corvus monedula $\mathrm{L}$. & Eurasian Jackdaw & Corvidae & N-R-UA-O & $\bullet$ & $\bullet$ & $\bullet$ & $\bullet$ \\
\hline Corvus cornix $\mathrm{L}$. & Hooded Crow & Corvidae & N-R-UE-O & $\bullet$ & $\bullet$ & $\bullet$ & $\bullet$ \\
\hline Garrulus glandarius L. & Eurasian Jay & Corvidae & N-R-UA-O & $\bullet$ & $\bullet$ & & \\
\hline Pica pica $\mathrm{L}$. & Eurasian Magpie & Corvidae & N-R-UA-O & $\bullet$ & $\bullet$ & & $\bullet$ \\
\hline Fringilla coelebs L. & $\begin{array}{l}\text { Common } \\
\text { Chaffinch }\end{array}$ & Fringillidae & N-R-UA-O & $\bullet$ & $\bullet$ & & \\
\hline Motacilla alba $\mathrm{L}$. & White Wagtail & Motacillidae & E-M-UA-I & $\bullet$ & & $\bullet$ & \\
\hline Motacilla cinerea Tunstall & Grey Wagtail & Motacillidae & E-M-UA-I & & & $\bullet$ & \\
\hline Motacilla flava $\mathrm{L}$. & $\begin{array}{l}\text { Western Yellow } \\
\text { Wagtail }\end{array}$ & Motacillidae & E-M-UA-I & $\bullet$ & & & \\
\hline Ficedula parva Bechstein & $\begin{array}{l}\text { Red-breasted } \\
\text { Flycatcher }\end{array}$ & Muscicapidae & E-M-UA-I & & $\bullet$ & & $\bullet$ \\
\hline Muscicapa striata Pallas & $\begin{array}{l}\text { Spotted } \\
\text { Flycatcher }\end{array}$ & Muscicapidae & E-M-UA-I & • & • & $\bullet$ & \\
\hline Cyanistes caeruleus $\mathrm{L}$. & Eurasian Blue Tit & Paridae & N-R-UA-I & $\bullet$ & $\bullet$ & & \\
\hline Parus major L. & Great Tit & Paridae & N-R-UA-I & $\bullet$ & $\bullet$ & $\bullet$ & $\bullet$ \\
\hline Passer domesticus $\mathrm{L}$. & House Sparrow & Passeridae & N-R-UE-O & $\bullet$ & $\bullet$ & $\bullet$ & $\bullet$ \\
\hline $\begin{array}{l}\text { Dendrocopos syriacus } \\
\text { (Hemprich \& Ehrenberg) }\end{array}$ & $\begin{array}{c}\text { Syrian } \\
\text { Woodpecker }\end{array}$ & Picidae & N-R-UA-I & $\bullet$ & $\bullet$ & & $\bullet$ \\
\hline Sitta europaea L. & \begin{tabular}{|l|} 
Eurasian \\
Nuthatch
\end{tabular} & Sittidae & N-R-UA-I & $\bullet$ & & & \\
\hline \multicolumn{4}{|c|}{ Number of Bird Species Observed: } & 14 & 12 & 8 & 8 \\
\hline
\end{tabular}

Note: *Status: Native or Exotic: N (Native), E (Exotic); Residency Status: R (Resident), M (Migrant); Urban Association: UA (Urban Adapter), UE (Urban Exploiter); Guild: G (Granivore), I (Insectivorous), O (Omnivorous); **Urban Parks: PRA (Pınarbasi Recreation Area), ARA (Aytepe Recreation Area), NBP (Nevzat BICER Park), ISP (Ismet SEZGIN Park) 
The Eurasian Collared-Dove (Streptopelia decaocto Frivaldszky), Eurasian Jackdaw (Corvus monedula L.), Hooded Crow (Corvus cornix L.), Great Tit (Parus major L.), and House Sparrow (Passer domesticus L.) that were observed in all parks were also the most frequently observed bird species in the parks. In the morning observations, the most frequently observed bird species were the Eurasian Jackdaw in the Pinarbasi Recreation Area, the Eurasian Jay (Garrulus glandarius L.) and Great Tit in the Aytepe Recreation Area, and the House Sparrow in Nevzat BICER and Ismet SEZGIN parks. In the evening observations, the most frequently observed bird species were the Eurasian Jackdaw and Eurasian Blue Tit (Cyanistes caeruleus L.) in the Pinarbasi Recreation Area, the Great Tit in the Aytepe Recreation Area, the House Sparrow in Nevzat BICER park, and the Eurasian Collared-Dove in Ismet SEZGIN Park (Table 2).

\section{Variation in bird species in relation to plant species in the study area}

In the Pinarbasi Recreation Area, the highest number of bird species was observed in the Australian Pine (Casuarina equisetifolia L.) (12 species), Turkish Pine (Pinus brutia Ten.) (9 species), and Oriental Plane Tree (Platanus orientalis L.) (8 species). The lowest number of bird species (1 species) was observed in the Japanese Spindle Tree (Euonymus japonicus Thunb.), Common Privet (Ligustrum vulgare L.), Oriental Sweetgum (Liquidambar orientalis Mill.), Japanese Pittosporum [Pittosporum tobira (Thunb.) W. T. Aiton], and Black Locust (Robinia pseudoacacia L.). The highest number of bird species observed in the Australian Pine were the Hooded Crow, Eurasian Jay, Eurasian Blue Tit, and Eurasian Nuthatch (Sitta europaea L.) (Table 3).

In the Pinarbasi Recreation Area, among the most frequently observed species in the parks examined, the great tit was observed in 12 tree species and 2 shrub species, the House Sparrow was observed in 10 tree species and 2 shrub species, the Eurasian Jackdaw was observed in 7 tree species, the Hooded Crow was observed in 5 tree species, the Eurasian Collared-Dove was observed in 3 tree species (Table 3). While the Western Yellow Wagtail (Motacilla flava L.), one species observed only in the Pinarbasi Recreation Area, was not observed in any tree, it was observed only on the ground.

In the Australian Pine, Turkish Pine, and Oriental Plane Tree that attracted the highest number of bird species in the Pinarbasi Recreation Area, most of the bird species were mostly observed in the morning observations. Other tree species on which birds were mostly observed in the morning observations were the Boxelder (Acer negundo L.), Italian Cypress [Cupressus sempervirens 'Horizontalis' (Mill.) Loudon], Stone Pine (Pinus pinea L.), Atlas Cedar [Cedrus atlantica (Endl.) Lindl.], and White Mulberry (Morus alba L.). In the Australian Pine and Turkish Pine, most of the bird species were also observed in the evening observations. Other species on which the bird species were mostly observed in the evening observations were the Boxelder, White Mulberry, Stone Pine, and Oriental Plane Tree (Table 3).

In the Aytepe Recreation Area, the highest number of bird species (11 species) and the lowest number of bird species ( 2 species) were observed in the Turkish Pine and Olive (Olea europaea L.), respectively. The Eurasian Collared-Dove, Eurasian Blue Tit, and Great Tit were most frequently observed in the Turkish Pine (Table 4).

In the Aytepe Recreation Area, among the most frequently observed species in the parks examined, the Eurasian Collared-Dove, Great Tit, and House Sparrow were most frequently observed in the Turkish Pine, and the Eurasian Jackdaw and Hooded Crow 
were most frequently observed in the Italian Cypress (Horizontal form) and Turkish Pine (Table 4).

Table 3. Plants on which birds were observed in the Pinarbasi Recreation Area and their time of observation

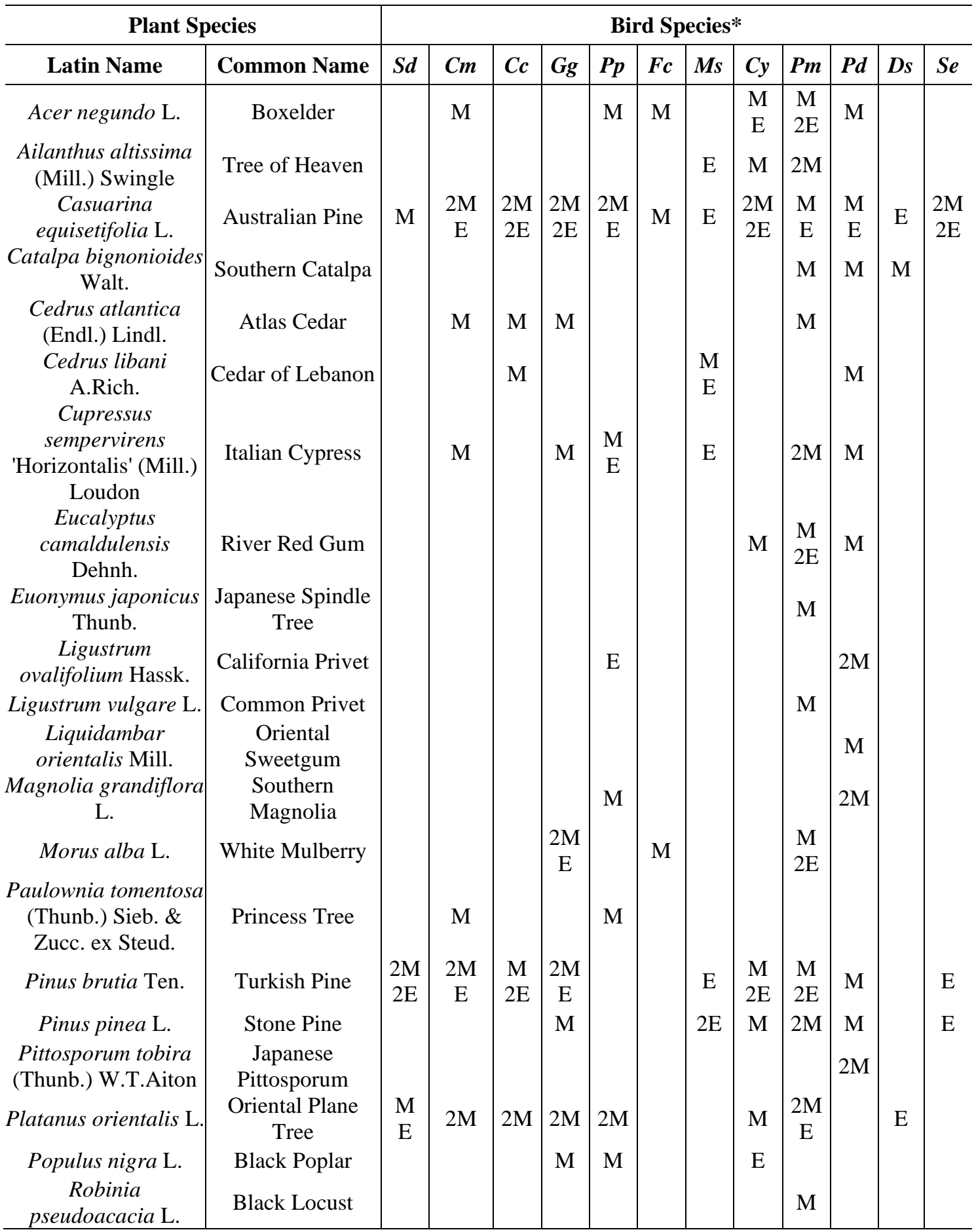

Note: Observation Time: M (Morning), E (Evening); *Bird Species: Sd (Streptopelia decaocto Frivaldszky), Cm (Corvus monedula L.), Cc (Corvus cornix L.), Gg (Garrulus glandarius L.), Pp (Pica pica L.), Fc (Fringilla coelebs L.), Ms (Muscicapa striata Pallas), Cy (Cyanistes caeruleus L.), Pm (Parus major L.), Pd (Passer domesticus L.), Ds (Dendrocopos syriacus (Hemprich \& Ehrenberg)), Se (Sitta europaea L.) 
Table 4. Plants on which birds were observed in the Aytepe Recreation Area and their time of observation

\begin{tabular}{c|c|c|c|c|c|c|c|c|c|c|c|c}
\hline \multicolumn{1}{c|}{ Plant Species } & \multicolumn{10}{|c}{ Bird Species* } \\
\hline Latin Name & Common Name & $\boldsymbol{S d}$ & $\boldsymbol{C m}$ & $\boldsymbol{C}$ & $\boldsymbol{G g}$ & $\boldsymbol{P p}$ & $\boldsymbol{F c}$ & $\boldsymbol{M} \boldsymbol{c}$ & $\boldsymbol{C} \boldsymbol{P}$ & $\boldsymbol{P m}$ & $\boldsymbol{P d}$ & $\boldsymbol{D} \boldsymbol{s}$ \\
\hline $\begin{array}{c}\text { Cupressus sempervirens } \\
\text { 'Horizontalis' (Mill.) } \\
\text { Loudon }\end{array}$ & Italian Cypress & $\mathrm{M}$ & $\mathrm{M}$ & $\mathrm{M}$ & & & & & & & & \\
Olea europaea L. & & $\mathrm{E}$ & $2 \mathrm{E}$ & & $2 \mathrm{M}$ & & & $\mathrm{M}$ & $2 \mathrm{M}$ & & \\
Oinus brutia Ten. & & & & & & & & & & & & \\
\hline
\end{tabular}

Note: Observation Time: M (Morning), E (Evening); *Bird Species: Sd (Streptopelia decaocto Frivaldszky), Cm (Corvus monedula L.), Cc (Corvus cornix L.), Gg (Garrulus glandarius L.), Pp (Pica pica L.), Fc (Fringilla coelebs L.), Ms (Muscicapa striata Pallas), Cy (Cyanistes caeruleus L.), Pm (Parus major L.), Pd (Passer domesticus L.), Ds (Dendrocopos syriacus (Hemprich \& Ehrenberg))

In the Aytepe Recreation Area, in the Turkish Pine that attracted the highest number of bird species, all bird species were observed in the morning observations. Another tree species on which birds were mostly observed in the morning observations was the Italian Cypress (Horizontal form). Most of the bird species in the Turkish Pine were also observed in the evening observations. Another species on which bird species were mostly observed in the evening observations was the Italian Cypress (Horizontal form) (Table 4).

In Nevzat BICER park, the highest number of bird species was observed in the Silky Oak (Grevillea robusta A. Cunn. ex R. Br.) (4 species). The lowest number of bird species was observed in (1 species each) 9 tree species, including the Tree of Heaven [Ailanthus altissima (Mill.) Swingle] and Silk Tree (Albizia julibrissin Durazz.), and in 2 shrub species comprising the California Privet (Ligustrum ovalifolium Hassk.) and Four-Stamen Tamarisk (Tamarix tetrandra Pall. ex M. Bieb.) (Table 5).

In Nevzat BICER park, among the most frequently observed species in the parks examined, the House Sparrow was observed in 15 tree species and 2 shrub species, the Eurasian Collared-Dove and Eurasian Jackdaw were observed in 9 tree species, and the Hooded Crow and Great Tit were observed in 1 tree species (Table 5). The Grey Wagtail (Motacilla cinerea Tunstall), which was observed only in Nevzat BICER park, was not observed in any tree; it was observed only on the ground.

In the Silky Oak that attracted the highest number of bird species in Nevzat BICER park, most of the bird species were observed in the morning observations. Other tree species on which the birds were mostly observed in the morning observations were the Boxelder, White Mulberry, and Japanese Pagoda Tree (Sophora japonica L.). The species on which bird species were mostly observed in the evening observations were the Boxelder and Russian Olive (Elaeagnus angustifolia L.). Other species on which bird species were mostly observed in the evening observations were the White Mulberry and Weeping Willow (Salix babylonica L.) (Table 5).

In Ismet SEZGIN park, while the highest number of bird species (6 species) was observed in the Australian Pine, the lowest number of bird species (1 species) was observed in the California Privet, Common Privet, White Mulberry, and Turkish Pine. The Eurasian Jackdaw was most frequently observed in the Australian Pine (Table 6). 
Table 5. Plants on which the birds were observed in Nevzat BICER Park and their time of observation

\begin{tabular}{|c|c|c|c|c|c|c|c|}
\hline \multicolumn{2}{|l|}{ Plant Species } & \multicolumn{6}{|c|}{ Bird Species* } \\
\hline Latin Name & Common Name & $S d$ & $\mathrm{Cm}$ & Cc & $M s$ & $P m$ & $P d$ \\
\hline Acer negundo L. & Boxelder & M & $2 \mathrm{M}$ & & & & $2 \mathrm{M}$ \\
\hline Acer saccharinum $\mathrm{L}$. & Silver Maple & $\mathrm{E}$ & M & & & & $2 \mathrm{E}$ \\
\hline Ailanthus altissima (Mill.) Swingle & Tree of Heaven & & & & & & M \\
\hline Albizia julibrissin Durazz. & Silk Tree & & & & & & M \\
\hline Carpinus betulus L. & Common Hornbeam & & & & & & $2 \mathrm{M}$ \\
\hline Cedrus atlantica (Endl.) Lindl. \& Gordon & Atlas Cedar & & M & & & & \\
\hline Cupressocyparis leylandii A.B.Jacks. \& Dallim & Leyland Cypress & $\mathrm{E}$ & & & & & $\mathrm{ME}$ \\
\hline Elaeagnus angustifolia $\mathrm{L}$. & Russian Olive & $\begin{array}{l}\mathrm{M} \\
\mathrm{F}\end{array}$ & $2 \mathrm{E}$ & & $\mathrm{E}$ & & \\
\hline Grevillea robusta A.Cunn. ex R.Br. & Silky Oak & M & M & M & & & $\mathrm{E}$ \\
\hline Jacaranda mimosifolia D. Don. & Jacaranda & $\begin{array}{l}\mathrm{M} \\
\mathrm{E}\end{array}$ & & & M & & $\begin{array}{l}\mathrm{M} \\
\mathrm{E}\end{array}$ \\
\hline Ligustrum ovalifolium Hassk. & California Privet & & & & & & M \\
\hline Magnolia grandiflora L. & Southern Magnolia & & & & & & M \\
\hline Morus alba L. & White Mulberry & $\begin{array}{c}2 \mathrm{M} \\
\mathrm{E}\end{array}$ & M & & & & $\begin{array}{l}M \\
2 \mathrm{E}\end{array}$ \\
\hline Platanus occidentalis L. & American Sycamore & & & & & $\mathrm{E}$ & \\
\hline Prunus cerasifera 'Atropurpurea' & $\begin{array}{l}\text { Purple-Leaf Cherry } \\
\text { Plum }\end{array}$ & & & & $\begin{array}{l}\mathrm{M} \\
\mathrm{E}\end{array}$ & & M \\
\hline Prunus domestica L & Plum & & & & M & & \\
\hline Prunus persica (L.) Batsch & Peach & M & M & & & & \\
\hline Robinia pseudoacacia L. & Black Locust & & & & $\mathrm{E}$ & & $2 \mathrm{M}$ \\
\hline Salix babylonica $\mathrm{L}$. & Weeping Willow & & & & $\mathrm{ME}$ & & $2 \mathrm{E}$ \\
\hline Sophora japonica L. & Japanese Pagoda Tree & $2 \mathrm{M}$ & M & & & & M \\
\hline Tamarix tetrandra Pall. ex M.Bieb. & Four-Stamen Tamarisk & & & & & & $\mathrm{M}$ \\
\hline $\begin{array}{l}\text { I llia cordata } \mathrm{M} 11 \mathrm{l} . \\
\text { Washingtonia robusta } \mathrm{H} \text {. Wendl. }\end{array}$ & $\begin{array}{l}\text { Small-Leaved Lim } \\
\text { Mexican Fan Palm }\end{array}$ & & M & & & & \\
\hline
\end{tabular}

Note: Observation Time: M (Morning), E (Evening); *Bird Species: Sd (Streptopelia decaocto Frivaldszky), Cm (Corvus monedula L.), Cc (Corvus cornix L.), Ms (Muscicapa striata Pallas), Pm (Parus major L.), Pd (Passer domesticus L.)

In Ismet SEZGIN Park, among the most frequently observed species in the parks examined, the House Sparrow was observed in 8 tree species and 2 shrub species, the Eurasian Collared-Dove and Eurasian Jackdaw were observed in 8 tree species, and the Hooded Crow and Great Tit were observed in 2 tree species (Table 6).

In the Australian Pine that attracted the highest number of bird species in Ismet SEZGIN Park, most of the bird species were observed in the morning observations. Other tree species on which the birds were mostly observed in the morning observations were the Italian Cypress [Cupressus sempervirens 'Pyramidalis' (O. Targ. Tozz.) Nyman], Stone Pine, Kurrajong (Brachychiton populneus Schott.), Oriental Plane Tree, and Small-Leaved Lime (Tilia cordata Mill.). The species on which bird species were mostly observed in the evening observations were the Stone Pine and Italian Cypress (Pyramidal form). Another species on which bird species were mostly observed in the evening observations was the Oriental Plane Tree (Table 6). 
Table 6. Plants on which the birds were observed in Ismet SEZGIN Park and their time of observation

\begin{tabular}{|c|c|c|c|c|c|c|c|c|c|}
\hline \multicolumn{2}{|l|}{ Plant Species } & \multicolumn{8}{|c|}{ Bird Species* } \\
\hline Latin Name & Common Name & $S d$ & $\mathrm{Cm}$ & $C c$ & $P p$ & $F p$ & $P m$ & $P d$ & $\overline{D s}$ \\
\hline Brachychiton populneus Schott. & Kurrajong & $\mathrm{M}$ & $2 \mathrm{M}$ & & & & $\mathrm{M}$ & $\mathrm{M}$ & \\
\hline Casuarina equisetifolia $\mathrm{L}$. & Australian Pine & $\begin{array}{l}\text { M } \\
\mathrm{E}\end{array}$ & $\begin{array}{c}2 \mathrm{M} \\
\mathrm{E}\end{array}$ & & M & $\mathrm{M}$ & & M & M \\
\hline $\begin{array}{c}\text { Cupressus sempervirens 'Pyramidalis' } \\
\text { (O.Targ.Tozz.) Nyman }\end{array}$ & Italian Cypress & $\begin{array}{c}2 \mathrm{M} \\
\mathrm{E}\end{array}$ & $\begin{array}{l}\mathrm{M} \\
2 \mathrm{E}\end{array}$ & M & & & & $\begin{array}{l}2 \mathrm{M} \\
2 \mathrm{E}\end{array}$ & \\
\hline Eucalyptus camaldulensis Dehnh. & River Red Gum & $\begin{array}{l}\mathrm{M} \\
\mathrm{E}\end{array}$ & & & & & & $\begin{array}{l}\mathrm{M} \\
\mathrm{E}\end{array}$ & \\
\hline Gleditsia triacanthos L. & Honey Locust & M & M & & & & M & & \\
\hline Ligustrum ovalifolium Hassk. & California Privet & & & & & & & $2 \mathrm{M}$ & \\
\hline Ligustrum vulgare $\mathrm{L}$. & Common Privet & & & & & & & $\mathrm{E}$ & \\
\hline Morus alba $\mathrm{L}$. & White Mulberry & & & & & & & $\begin{array}{c}2 \mathrm{M} \\
\mathrm{E}\end{array}$ & \\
\hline Pinus brutia Ten. & Turkish Pine & & M & & & & & & \\
\hline Pinus pinea $\mathrm{L}$. & Stone Pine & $\begin{array}{c}2 \mathrm{M} \\
2 \mathrm{E}\end{array}$ & $\begin{array}{l}2 \mathrm{M} \\
2 \mathrm{E}\end{array}$ & & & $\mathrm{E}$ & & $\begin{array}{c}2 \mathrm{M} \\
\mathrm{E}\end{array}$ & \\
\hline Platanus orientalis $\mathrm{L}$. & $\begin{array}{l}\text { Oriental Plane } \\
\text { Tree }\end{array}$ & $\mathrm{M}$ & $\begin{array}{c}2 \mathrm{M} \\
\mathrm{E}\end{array}$ & & & & & $\begin{array}{l}2 \mathrm{M} \\
2 \mathrm{E}\end{array}$ & \\
\hline Tilia cordata Mill. & $\begin{array}{l}\text { Small-Leaved } \\
\text { Lim }\end{array}$ & M & $2 \mathrm{M}$ & M & & & & $\begin{array}{l}\mathrm{M} \\
\mathrm{E}\end{array}$ & \\
\hline
\end{tabular}

Note: Obsevation Time: M (Morning), E (Evening); *Bird Species: Sd (Streptopelia decaocto Frivaldszky), Cm (Corvus monedula L.), Cc (Corvus cornix L.), Pp (Pica pica L.), Fp ( Ficedula parva Bechstein), Pm (Parus major L.), Pd (Passer domesticus L.), Ds (Dendrocopos syriacus (Hemprich \& Ehrenberg))

The Australian Pine attracted the highest number of bird species with 12 species, followed by the Turkish Pine with 11 species. Other plants that attracted the highest number of bird species were the Oriental Plane Tree with 8 species, and the Boxelder, Italian Cypress (Horizontal form), and Stone Pine with 6 species. Four of the six plant species that attracted the highest number of bird species were native species.

Native, resident, insectivorous and omnivorous birds show significant variance ( $p<0.05$ ), depending on the location of the park, according to the results of the Mann Whitney $U$ test. Depending on the location of the park, it has been determined that urban adapter and urban exploiter birds do not show significant variance. Native and urban adapter birds show significant variance between shrubs and trees; between broadleaved and coniferous plants, native, urban adapter, urban exploiter, insectivorous and omnivorous birds show significant variance $(p<0.05)$. Depending on the park location, plant species and the type of plant leaf, avian diversity shows a significant variance (Table 7). As there is no significant variance between native and exotic tree species and bird species and avian diversity, this is not included in the table.

The results of the Kruskal Wallis test are shown in Table 8, which shows bird species and avian diversity depending on the height of the plant. A statistically significant variance was observed between plant heights for native birds, omnivorous birds and levels of avian diversity, based on the test results $(p<0.05)$. The level of attraction of native birds is much higher for high-sized plants than for short-sized plants; the level of attraction of native birds is significantly higher for medium-sized plants than short-sized 
plants. In attracting omnivorous birds from higher plants to shorter plants, there is a significant variance. More omnivorous birds than short plants are attracted by higher plants. There is a significant variance in avian diversity between the likelihood of finding more birds in high and medium-sized plants than in short-sized plants (Table 8).

Table 7. Calculation results of Mann-Whitney $U$ test on bird species and avian diversity related to park location, plant species and leaf type

\begin{tabular}{|c|c|c|c|c|}
\hline Bird Species & Park Location & Mean Rank & $\mathbf{U}$ & $p$ \\
\hline Native & $\begin{array}{l}\text { Urban Center } \\
\text { Urban Fringe }\end{array}$ & $\begin{array}{l}25.09 \\
34.78\end{array}$ & 524 & $0.025 *$ \\
\hline Resident & $\begin{array}{l}\text { Urban Center } \\
\text { Urban Fringe }\end{array}$ & $\begin{array}{c}7.5 \\
17.86\end{array}$ & 144 & $0.002 *$ \\
\hline Urban Adapter & $\begin{array}{l}\text { Urban Center } \\
\text { Urban Fringe }\end{array}$ & $\begin{array}{l}20.46 \\
26.82\end{array}$ & 337 & 0.096 \\
\hline Urban Exploiter & $\begin{array}{l}\text { Urban Center } \\
\text { Urban Fringe }\end{array}$ & $\begin{array}{l}21.61 \\
25.29\end{array}$ & 277 & 0.121 \\
\hline Insectivorous & $\begin{array}{l}\text { Urban Center } \\
\text { Urban Fringe }\end{array}$ & $\begin{array}{l}10.71 \\
19.34\end{array}$ & 177.5 & $0.008 *$ \\
\hline Omnivorous & $\begin{array}{l}\text { Urban Center } \\
\text { Urban Fringe }\end{array}$ & $\begin{array}{l}21.77 \\
34.08\end{array}$ & 471.5 & $0.002 *$ \\
\hline Avian Diversity & $\begin{array}{l}\text { Urban Center } \\
\text { Urban Fringe }\end{array}$ & $\begin{array}{l}25.74 \\
36.21 \\
\end{array}$ & 569 & $0.018 *$ \\
\hline Bird Species & Plant Species & Mean Rank & $\mathbf{U}$ & $p$ \\
\hline Native & $\begin{array}{c}\text { Shrub } \\
\text { Tree }\end{array}$ & $\begin{array}{l}13.36 \\
31.19\end{array}$ & 284.5 & $0.006^{*}$ \\
\hline Resident & $\begin{array}{l}\text { Shrub } \\
\text { Tree }\end{array}$ & $\begin{array}{c}9.88 \\
15.82\end{array}$ & 70.5 & 0.203 \\
\hline Urban Adapter & $\begin{array}{l}\text { Shrub } \\
\text { Tree }\end{array}$ & $\begin{array}{c}8.5 \\
24.55\end{array}$ & 109.5 & $0.041 *$ \\
\hline Urban Exploiter & $\begin{array}{l}\text { Shrub } \\
\text { Tree }\end{array}$ & $\begin{array}{c}20 \\
23.38\end{array}$ & 115 & 0.611 \\
\hline Insectivorous & $\begin{array}{l}\text { Shrub } \\
\text { Tree }\end{array}$ & $\begin{array}{c}10.5 \\
16.38\end{array}$ & 40 & 0.430 \\
\hline Omnivorous & $\begin{array}{l}\text { Shrub } \\
\text { Tree }\end{array}$ & $\begin{array}{l}17.40 \\
27.47\end{array}$ & 163 & 0.168 \\
\hline Avian Diversity & $\begin{array}{c}\text { Shrub } \\
\text { Tree } \\
\end{array}$ & $\begin{array}{l}12.64 \\
32.34 \\
\end{array}$ & 303.5 & $0.003 *$ \\
\hline Bird Species & Leaf Type & Mean Rank & $\mathbf{U}$ & $p$ \\
\hline Native & $\begin{array}{c}\text { Broad-leaved } \\
\text { Coniferous }\end{array}$ & $\begin{array}{l}25.53 \\
40.73\end{array}$ & 133.5 & $0.003 *$ \\
\hline Resident & $\begin{array}{c}\text { Broad-leaved } \\
\text { Coniferous }\end{array}$ & $\begin{array}{l}13.88 \\
17.94\end{array}$ & 60.5 & 0.257 \\
\hline Urban Adapter & $\begin{array}{l}\text { Broad-leaved } \\
\text { Coniferous }\end{array}$ & $\begin{array}{l}20.33 \\
31.54\end{array}$ & 110 & $0.008 *$ \\
\hline Urban Exploiter & $\begin{array}{l}\text { Broad-leaved } \\
\text { Coniferous }\end{array}$ & $\begin{array}{c}20.7 \\
28.65\end{array}$ & 134.5 & $0.002 *$ \\
\hline Insectivorous & $\begin{array}{c}\text { Broad-leaved } \\
\text { Coniferous }\end{array}$ & $\begin{array}{c}13.33 \\
21.6\end{array}$ & 49 & $0.017 *$ \\
\hline Omnivorous & $\begin{array}{c}\text { Broad-leaved } \\
\text { Coniferous }\end{array}$ & $\begin{array}{c}22.8 \\
36.54\end{array}$ & 125.5 & $0.002 *$ \\
\hline Avian Diversity & $\begin{array}{c}\text { Broad-leaved } \\
\text { Coniferous }\end{array}$ & $\begin{array}{l}25.72 \\
43.75 \\
\end{array}$ & 122.5 & $0.000 *$ \\
\hline
\end{tabular}

Note: * the significance level $(p)<0.05$ 
Table 8. Calculation results of Kruskal-Wallis test on bird species and avian diversity related to plant size

\begin{tabular}{c|c|c|c|c|c|c|c}
\hline Bird Species & \multicolumn{2}{|c|}{ Plant Size } & $\begin{array}{c}\text { Test } \\
\text { Statistic }\end{array}$ & $\begin{array}{c}\text { Std. } \\
\text { Error }\end{array}$ & $\begin{array}{c}\text { Std. Test } \\
\text { Statistic }\end{array}$ & $\boldsymbol{p}$ & **Adjusted $\boldsymbol{p}$ \\
\hline \multirow{3}{*}{ Native } & Short & High & -16.393 & 5.250 & -3.123 & 0.002 & $0.005^{*}$ \\
& Short & Medium & -17.787 & 6.568 & -2.708 & 0.007 & $0.020^{*}$ \\
& High & Medium & 1.394 & 5.581 & 0.250 & 0.803 & 1 \\
\hline \multirow{3}{*}{ Omnivorous } & Short & High & -16.344 & 4.944 & -3.306 & 0.001 & $0.003^{*}$ \\
& Short & Medium & -8.500 & 5.981 & -1.591 & 0.155 & 0.466 \\
& Medium & High & -7.844 & 4.944 & -1.586 & 0.113 & 0.338 \\
\hline \multirow{3}{*}{ Avian Diversity } & Short & High & -17.080 & 5.292 & -3.228 & 0.001 & $0.004^{*}$ \\
& Short & Medium & -18.468 & 6.714 & -2.750 & 0.006 & $0.018^{*}$ \\
& High & Medium & 1.388 & 5.781 & 0.240 & 0.810 & 1 \\
\hline
\end{tabular}

Note: * the significance level $(p)<0.05$ and $* *$ significance values have been adjusted by the bonferroni correction for multiple tests

\section{Discussion}

Many birds are usually observed in urban environments. However, very few of them are native species (McCurdy, 2016). However, native species made up most bird species (11 species/68.75\%) observed in the four urban parks examined in Aydin city.

The species common in urban landscapes are exotic exploiters or general native species tolerant to various urban conditions (White et al., 2005; Antos, 2006; McKinney, 2006). Resident species dominated the bird community in the city center and made up over $90 \%$ of the species observed. However, their number decreased as the building density decreased (McCurdy, 2016). All bird species observed in this study comprised urban adapter (5 exotic and 9 native species/87.5\%) and urban exploiter (2 native species/12.5\%) species. Resident species (11 species) made up most of the bird species observed $(68.75 \%)$. However, they increased (towards the urban fringe) as the building density decreased.

The ratio of granivores in the bird community reaches a maximum in the city center $(23 \%)$, and the ratio of the species in this group decreased towards natural regions and reached 8\% (McCurdy, 2016). In this study, only one granivore species (Eurasian Collared-Dove) was identified. The number of insectivorous species with the highest ratio $(56.25 \%)$ in the bird population increased towards natural areas.

In the studies investigating bird diversity in the USA (Tucson), Canada (Quebec), Germany (Leipzig), Scotland (St. Andrews), and Israel (Tel-Aviv), it was determined that the synanthropic species, including urban adapter and urban exploiter species such as the House Sparrow, Rock Dove (Columba livia Gmelin), Common Starling (Sturnus vulgaris L.), Eurasian Magpie (Pica pica L.), Eurasian Blackbird (Turdus merula L.), Hooded Crow, Eurasian Jackdaw, European Robin (Erithacus rubecula L.), and Great Tit, were the common bird species in cities (Shwartz et al., 2008; Strohbach et al., 2009; Carbó-Ramírez and Zuria, 2011; Camacho-Cervantes et al., 2018; Hensley et al., 2019). In this study, the Eurasian Collared-Dove, Eurasian Jackdaw, Hooded Crow, Great Tit, and House Sparrow were most frequently observed in the parks, and similar results were obtained. 
Similarly to the results of previous studies (White et al., 2005; Shwartz et al., 2008; Yang et al., 2015), the results also revealed that the woody plant species richness had a positive effect on bird species richness. Specific habitat characteristics that have been effective in increasing bird species diversity in urban green areas are tall tree woodlands and hollow old trees (Fernández-Juricic, 2004; Sandström et al., 2006; Stagoll et al., 2012; Threlfall et al., 2016). During the winter months, insectivorous species are more frequently observed in wider green areas with more tree and shrub species and in taller trees (Carbó-Ramírez and Zuria, 2011). Insectivorous bird species such as the Spotted Flycatcher (Muscicapa striata Pallas), Eurasian Blue Tit, Great Tit, Syrian Woodpecker [Dendrocopos syriacus (Hemprich \& Ehrenberg)], and Eurasian Nuthatch were more frequently observed in tall coniferous trees, such as Atlas Cedar, Cedar of Lebanon (Cedrus libani A. Rich.), Italian Cypress (Horizontal form), Turkish Pine, and Stone Pine, and in tall broad-leaved trees such as the Tree of Heaven, Boxelder, Australian Pine, Southern Catalpa (Catalpa bignonioides Walt.), River Red Gum (Eucalyptus camaldulensis Dehnh.), White Mulberry, Oriental Plane Tree, Black Poplar (Populus nigra L.), and Black Locust in the Pinarbasi Recreation Area and Aytepe Recreation Area with more tree and shrub species and the wider area. Older and taller trees are more likely to have hollows compared to smaller trees (Carlson et al., 1998; Manning et al., 2006; Lindenmayer et al., 2014), and Woodpeckers, hollow-nesting species and forest birds increase from the city center to the periphery (Sandström et al., 2006). Under this view, the Eurasian Blue Tit, Syrian Woodpecker, and Eurasian Nuthatch, which are hollow-nesting species, were observed in the old and tall coniferous and broad-leaved trees in the Pinarbasi Recreation Area and Aytepe Recreation Area near the urban fringe.

There is a relationship between bird species richness and vegetation structure. The features of the vegetation structure are important for birds in urban areas (Lancaster and Rees, 1979; Mills et al., 1989; Fernández-Juricic, 2004). That the Eurasian Jay and Common Chaffinch (Fringilla coelebs L.) were observed in coniferous and broadleaved tree species comprising the Boxelder, Australian Pine, Atlas Cedar, Italian Cypress (Horizontal form), White Mulberry, Turkish Pine, Stone Pine, Oriental Plane Tree, and Black Poplar supports the view that these bird species are observed in all kinds of woodlands (Bloomsbury, 2019).

The bird species richness in the Pinarbasi Recreation Area with more deciduous trees was found to be higher than the bird species richness in the Aytepe Recreation Area with more coniferous trees. This result is compatible with the view that the bird species richness is higher in parks where there are more deciduous trees than coniferous trees (Thompson et al., 1993). But it has been observed that the richness of coniferous trees for bird species is higher than broad-leaved trees.

Well-protected understory may provide birds with abundant hunting products such as arthropods (Kirchner, 1977; Conner et al., 1986; Keller et al., 2003). The abundant food source enabled the observation of the Eurasian Magpie, Great Tit, and House Sparrow in the shrubs formed by the Japanese Spindle Tree, California Privet, Common Privet, Japanese Pittosporum, and Four-Stamen Tamarisk that made up the understory. While the House Sparrow was observed in four of five shrub species, the Great Tit, the only insectivorous species among these species, was observed in the Japanese Spindle Tree and Common Privet. So, doubling the vegetation layers significantly increases the number of insectivorous bird species in particular (Threlfall et al., 2016). 
There is a significant relationship between bird diversity and the amount of natural vegetation (Sandström et al., 2006; Threlfall et al., 2016; Muñoz-Pedreros et al., 2018). The diversity of bird species increases as the vegetation increases towards the urban fringe (Blair, 1999; Sandström et al., 2006). Since vegetation is usually exotic, there is an increase in the diversity of exotic bird species. However, sometimes, native vegetation allows for a higher proportion of native bird species (White et al., 2005; Chace and Walsh, 2006; Daniels and Kirkpatrick, 2006; Threlfall et al., 2016). Although the variance in this study is not statistically significant, when consideration is given to observed bird species and plant species, the number of native bird species was found to be higher in the Pinarbasi Recreation Area and Aytepe Recreation Area on the urban fringe where there were more native tree species, which was due to the fact that high diversity in natural vegetation provided more nesting space, shelter, and food for many bird species (Chong et al., 2014).

The Grey Wagtail and Western Yellow Wagtail have specific habitat requirements; such as being observed only in open vegetative areas (Yang et al., 2015). Likewise, the White Wagtail (Motacilla alba L.), Grey Wagtail, and Western Yellow Wagtail were observed in open areas by the pool in the Pinarbasi Recreation Area and Nevzat BICER park.

The Eurasian Jackdaw, Hooded Crow, and House Sparrow were three of the most frequently observed species in all parks since they are omnivorous species, are not selective in terms of food, and are highly adapted to urban conditions. The Great Tit and Eurasian Collared-Dove, which are the other species most frequently observed in the parks, are highly adapted to urban conditions.

While the trees on which the birds were observed in the morning provide food, the trees on which the birds were observed in the evening provide shelter. The reason the Australian Pine, Turkish Pine, and Oriental Plane Tree in the Pinarbasi Recreation Area attracted the highest number of bird species is that they are usually a food source for birds. In the Pinarbasi Recreation Area, the Australian Pine and Turkish Pine also attract most bird species at night and provide them with shelter.

The Turkish Pine, which attracted the highest number of bird species in the Aytepe Recreation Area, offers food for all bird species and shelter for most of them. The Italian Cypress (Horizontal form) is another species that is mostly a food source for most of the bird species.

The reason the Silky Oak in Nevzat BICER park attracted the highest number of bird species is that it is mostly a food source for birds. The Boxelder, White Mulberry, and Japanese Pagoda Tree, other tree species on which the birds were mostly observed in the morning observations, are also mostly food sources for birds. The Boxelder and Russian Olive, on which bird species were mostly observed in the evening, mostly serve as a shelter for birds. Since the Silver Maple (Acer saccharinum L.) has a dense texture, it is used for spending the night by the House Sparrows. The dense leaves of the tree allow the birds to hide from predators at night.

In Ismet SEZGIN Park, the Australian Pine attracts the highest number of bird species because it is a food source for birds. The Italian Cypress (Pyramidal form), Stone Pine, Kurrajong, Oriental Plane Tree, and Small-Leaved Lime, other tree species on which the birds are mostly observed in the morning, are also food sources for birds. The Stone Pine and Italian Cypress (Pyramidal form), on which bird species are mostly observed in the evening, also serve as a shelter. 
The birds were intensely observed in the trees in the parks examined in the study because trees are more sheltered from attacks by predators such as cats because of their height. Small shrubs are rarely used as they leave birds vulnerable to attack by cats living in parks.

\section{Conclusions}

Understanding the relationships between biodiversity and urban green areas is important for the management and especially conservation of urban green areas (Temple and Wiens, 1989; Ives et al., 2016; Ibáñez-Álamo et al., 2017). To understand the vegetation and to associate it with wildlife activity and pattern in a particular area are considered to be the best approaches for predicting the species that can use a metropolitan area and their capacity (Morrison et al., 1992; Clergeau et al., 1998).

The relationship between native bird species and native plants was found to be higher compared to exotic plants (Donnelly and Marzluff, 2004; Daniels and Kirkpatrick, 2006). The heterogeneity of native vegetation makes up the best starting point for the conservation of native bird species diversity in urban environments and the minimization of urban exploiter and exotic species (Chace and Walsh, 2006; Palmer et al., 2008; Shwartz et al., 2008).

It is necessary to give priority to natural or semi-natural vegetation for the management of urban areas that support bird wildlife, and the species that require high maintenance should be considered as a second option (Chong et al., 2014). Rather than exotic woody species, different native plant species should be mainly used in urban parks because of their low water requirements and their compatibility with the soil structure and climate of the region (Livingston et al., 2003; Chace and Walsh, 2006; Daniels and Kirkpatrick, 2006; Burghardt et al., 2009). Native trees, shrubs, and groundcovers are very important since they are sources of food and nectar and attract many insects that birds feed on. Birds are fed with the seeds of these native plants and the insects they attract. Therefore, native plants are important parts of a wildlife park focusing on bird habitat (Bauer, 2012).

The ratio of shrubs and trees of different sizes should be increased in urban parks of Aydin to increase bird diversity. Native plant species that attract native bird species should be used in the planting design studies of the parks to be built in Aydin and other cities in Turkey and the world (Table 9).

While the White Mulberry and Turkish Pine should be used if the Eurasian Jay is desired to be invited to parks, the Italian Cypress (Horizontal form), Turkish Pine, and Oriental Plane Tree should be used if the Eurasian Magpie is desired to be invited, the Turkish Pine should be used if the Common Chaffinch is desired, the Stone Pine should be used if the Red-Breasted Flycatcher (Ficedula parva Bechstein) is desired to be invited, the Cedar of Lebanon, Turkish Pine, and Stone Pine should be used if the Spotted Flycatcher is desired, the Turkish Pine should be used if the Eurasian Blue Tit is desired to be invited, the White Mulberry, Turkish Pine, and Oriental Plane Tree should be used if the great tit is desired to be invited, the Turkish Pine and Oriental Plane Tree should be used if the Syrian Woodpecker is desired, and the Turkish Pine and Stone Pine should be used if the Eurasian Nuthatch is desired to be invited.

The Turkish Pine, Oriental Plane Tree, Italian Cypress (Horizontal form), Stone Pine, and White Mulberry should be planted in parks as food sources for the Eurasian Jay, 
Great Tit, Eurasian Magpie, Eurasian Blue Tit and Common Chaffinch, Spotted Flycatcher and Syrian Woodpecker.

Table 9. Native plant species that attract bird species in parks (developed from Bradbury, 2019)

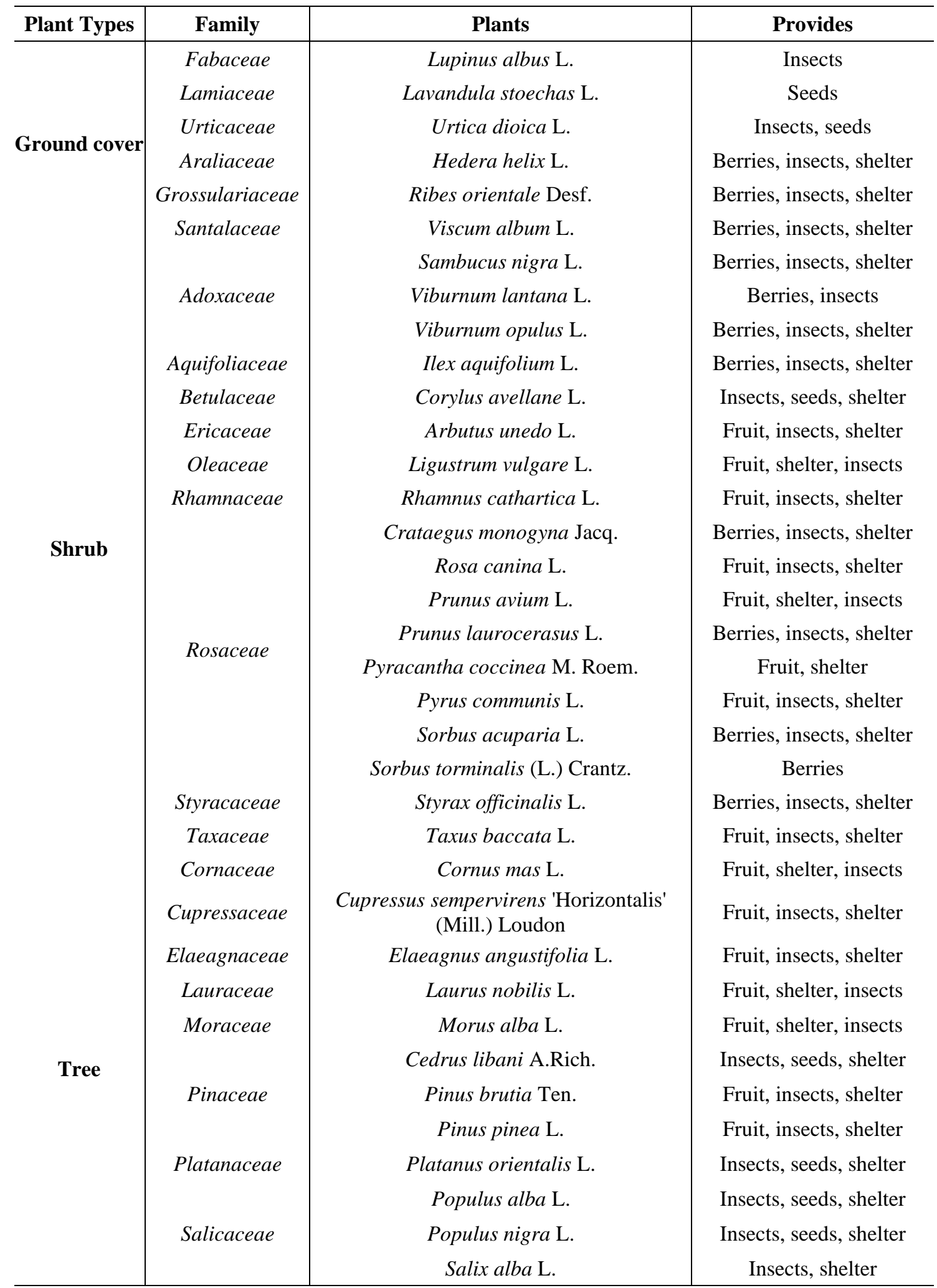


The Italian Cypress (Horizontal form), Russian Olive, Turkish Pine, White Mulberry, Stone Pine, and Oriental Plane Tree should be used in the planting of parks since they provide shelter for the Great Tit, Spotted Flycatcher, Eurasian Jay, Common Chaffinch, Red-Breasted Flycatcher, Eurasian Blue Tit, Eurasian Nuthatch, and Syrian Woodpecker.

Rather than being an aesthetic element, parks should be a network of life where nature is imitated and a mini-ecosystem in which birds, bees, insects, and other creatures live. Thus, parks that support wildlife will also increase bird diversity (Bauer, 2012).

The planting design should be included in future studies if it is aimed to protect high natural biodiversity in urban parks.

Acknowledgements. The authors received no financial support for the research, authorship, and/or publication of this article. Both authors were involved in all phases of the work. The authors declare that they have no competing interests. All data generated or analyzed during this study are included in this published article.

\section{REFERENCES}

[1] Akkemik, U. (2018): Turkiye'nin dogal-egzotik agac ve calilari. - T. C. Orman ve Su Isleri Bakanligi Orman Genel Mudurlugu, Ankara.

[2] Antos, M. J., Fitzsimons, J. A., Palmer, G. C., White, J. G. (2006): Introduced birds in urban remnant vegetation: Does remnant size really matter? - Austral Ecology 31(2): 254-261. doi: 10.1111/j.1442-9993.2006.01572.x.

[3] AOU. (2009): Fiftieth supplement to the american ornithologists' union check-list of north american birds. - The Auk 126(3): 705-714. doi: 10.1525/auk.2009.8709.

[4] Aronson, M. F. J., La Sorte, F. A., Nilon, C. H., Katti, M., Goddard, M. A., Lepczyk, C. A., Warren, P. S., Williams, N. S. G., Cilliers, S., Clarkson, B., Dobbs, C., Dolan, R., Hedblom, M., Klotz, S., Kooijmans, J. L., Kühn, I., Macgregor-Fors, I., McDonnell, M., Mörtberg, U., Pyšek, P., Siebert, S., Sushinsky, J., Werner, P., Winter, M. (2014): A global analysis of the impacts of urbanization on bird and plant diversity reveals key anthropogenic drivers. - Proceedings of the Royal Society B: Biological Sciences 281(1780): 20133330. doi: 10.1098/rspb.2013.3330.

[5] Baines, C. (2000): How to make a wildlife garden ( $2^{\text {nd }}$ Rev ed.). - Frances Lincoln, London.

[6] Baldock, K. C. R., Goddard, M. A., Hicks, D. M., Kunin, W. E., Mitschunas, N., Osgathorpe, L. M., Potts, S. G., Robertson, K. M., Scott, A. V., Stone, G. N., Vaughan, I. P., Memmott, J. (2015): Where is the UK's pollinator biodiversity? The importance of urban areas for flower-visiting insects. - Proceedings of the Royal Society B: Biological Sciences 282(1803): 20142849. doi: 10.1098/rspb.2014.2849.

[7] Bauer, N. (2012): The california wildlife habitat garden: How to attract bees, butterflies, birds, and other animals ( $1^{\text {st }}$ ed.). - University of California Press, California.

[8] Beninde, J., Veith, M., Hochkirch, A. (2015): Biodiversity in cities needs space: A metaanalysis of factors determining intra-urban biodiversity variation. - Ecology Letters 18(6): 581-592. doi: 10.1111/ele.12427.

[9] BirdLife-International. (2011): Species accounts. - Retrieved September 2019, from www.birdlife.org

[10] Blair, R. B. (1996): Land use and avian species diversity along an urban gradient. Ecological Applications 6(2): 506-519. doi: 10.2307/2269387. 
[11] Blair, R. B. (1999): Birds and butterflies along an urban gradient: Surrogate taxa for assessing biodiversity? - Ecological Applications 9(1): 164-170. doi: 10.1890/1051-0761.

[12] Bloomsbury. (2019): Concise garden wildlife guide (1 ${ }^{\text {st }}$ ed.). - Bloomsbury Wildlife, London.

[13] Bradbury, K. (2019): Wildlife gardening: For everyone and everything. - Bloomsbury Wildlife, London.

[14] Braden, G. T., Crew, L., Miller, A. (2007): Avian diversity, vegetation composition, and vegetation structure of the Las Vegas Wash: Year one - final report. - Las Vegas Wash Coordination Committee, Redlands.

[15] Burghardt, K. T., Tallamy, D. W., Gregory Shriver, W. (2009): Impact of native plants on bird and butterfly biodiversity in suburban landscapes. - Conservation Biology 23(1): 219-224. doi: 10.1111/j.1523-1739.2008.01076.x.

[16] Callaghan, C. T., Major, R. E., Lyons, M. B., Martin, J. M., Kingsford, R. T. (2018): The effects of local and landscape habitat attributes on bird diversity in urban greenspaces. Ecosphere 9(7): e02347. doi: 10.1002/ecs2.2347.

[17] Camacho-Cervantes, M., Ojanguren, A. F., Macgregor-Fors, I. (2018): Birds from the burgh: Bird diversity and its relation with urban traits in a small town. - Journal of Urban Ecology 4(1): juy011. doi: 10.1093/jue/juy011.

[18] Carbó-Ramírez, P., Zuria, I. (2011): The value of small urban greenspaces for birds in a Mexican city. - Landscape and Urban Planning 100(3): 213-222. doi: 10.1016/j.landurbplan.2010.12.008.

[19] Carlson, A., Sandström, U., Olsson, K. (1998): Availability and use of natural tree holes by cavity nesting birds in a Swedish deciduous forest. - Ardea 86(1): 109-119.

[20] Carvajal-Castro, J. D., Ospina-L, A. M., Toro-López, Y., Pulido-G, A., Cabrera-Casas, L. X., Guerrero-Peláez, S., García-Merchán, V. H., Vargas-Salinas, F. (2019): Birds vs bricks: Patterns of species diversity in response to urbanization in a Neotropical Andean city. - PLoS ONE 14(6): e0218775. doi: 10.1371/journal.pone.0218775.

[21] Chace, J. F., Walsh, J. J. (2006): Urban effects on native avifauna: A review. - Landscape and Urban Planning 74(1): 46-69. doi: 10.1016/j.landurbplan.2004.08.007.

[22] Chong, K. Y., Teo, S., Kurukulasuriya, B., Chung, Y. F., Rajathurai, S., Tan, H. T. W. (2014): Not all green is as good: Different effects of the natural and cultivated components of urban vegetation on bird and butterfly diversity. - Biological Conservation 171: 299-309. doi: 10.1016/j.biocon.2014.01.037.

[23] Clergeau, P., Savard, J.-P. L., Mennechez, G., Falardeau, G. (1998): Bird abundance and diversity along an urban-rural gradient: A comparative study between two cities on different continents. - The Condor 100(3): 413-425. doi: 10.2307/1369707.

[24] Conner, R. N., Anderson, M. E., Dickson, J. G. (1986): Relationships among territory size, habitat, song, and nesting success of northern cardinals. - The Auk 103(1): 23-31. doi: 10.1093/auk/103.1.23.

[25] Cornelis, J., Hermy, M. (2004): Biodiversity relationships in urban and suburban parks in Flanders. - Landscape and Urban Planning 69(4): 385-401. doi: 10.1016/j.landurbplan.2003.10.038.

[26] Daniels, G. D., Kirkpatrick, J. B. (2006): Does variation in garden characteristics influence the conservation of birds in suburbia? - Biological Conservation 133(3): 326335. doi: 10.1016/j.biocon.2006.06.011.

[27] Donnelly, R., Marzluff, J. M. (2004): Importance of reserve size and landscape context to urban bird conservation. - Conservation Biology 18(3): 733-745. doi: 10.1111/j.15231739.2004.00032.x.

[28] eBird. (2012): eBird: An online database of bird distribution and abundance [web application]. - Retrieved September 2019, from http://www.ebird.org.

[29] Emlen, J. T. (1974): An urban bird community in Tucson, Arizona: Derivation, structure, regulation. - The Condor 76(2): 184-197. doi: 10.2307/1366729. 
[30] Fernández-Juricic, E., Jokimäki, J. (2001): A habitat island approach to conserving birds in urban landscapes: case studies from southern and northern Europe. - Biodiversity and Conservation 10(12): 2023-2043. doi: 10.1023/a:1013133308987.

[31] Fernández-Juricic, E. (2004): Spatial and temporal analysis of the distribution of forest specialists in an urban-fragmented landscape (Madrid, Spain): Implications for local and regional bird conservation. - Landscape and Urban Planning 69(1): 17-32. doi: 10.1016/j.landurbplan.2003.09.001.

[32] Filloy, J., Zurita, G. A., Bellocq, M. I. (2019): Bird diversity in urban ecosystems: The role of the biome and land use along urbanization gradients. - Ecosystems 22(1): 213227. doi: 10.1007/s10021-018-0264-y.

[33] Fontana, S., Sattler, T., Bontadina, F., Moretti, M. (2011a): How to manage the urban green to improve bird diversity and community structure. - Landscape and Urban Planning 101(3): 278-285. doi: 10.1016/j.landurbplan.2011.02.033.

[34] Fontana, C. S., Burger, M. I., Magnusson, W. E. (2011b): Bird diversity in a subtropical South-American City: Effects of noise levels, arborisation and human population density. - Urban Ecosystems 14(3): 341-360. doi: 10.1007/s11252-011-0156-9.

[35] Gil, D., Brumm, H. (2014): Avian urban ecology: Behavioural and physiological adaptations ( $1^{\text {st }}$ ed.). - Oxford University Press, Oxford.

[36] Gilbert, O. L. (1989): The ecology of urban habitats $\left(11^{\text {th }}\right.$ ed.). - Chapman and Hall, London.

[37] Gill, F., Donsker, D. (2020): IOC world bird list (v 10.2). - Retrieved 12 July 2020, from http://www.worldbirdnames.org.

[38] Goertzen, D., Suhling, F. (2015): Central European cities maintain substantial dragonfly species richness - a chance for biodiversity conservation? - Insect Conservation and Diversity 8(3): 238-246. doi: 10.1111/icad.12102.

[39] Hadidian, J., Sauer, J., Swarth, C., Handly, P., Droege, S., Williams, C., Huff, J., Didden, G. (1997): A citywide breeding bird survey for Washington, D.C. - Urban Ecosystems 1(2): 87-102. doi: 10.1023/A:1018563125184.

[40] Heinzel, H., Fitter, R., Parslow, J. (1995): Birds of Britain and Europe with North Africa and the Middle East ( $5^{\text {th }}$ ed.). - Rotolito Lombarda, Italy.

[41] Hensley, C. B., Trisos, C. H., Warren, P. S., Macfarland, J., Blumenshine, S., Reece, J., Katti, M. (2019): Effects of urbanization on native bird species in three southwestern US cities. - Frontiers in Ecology and Evolution 7: 71. doi: 10.3389/fevo.2019.00071.

[42] Howell, S., Webb, S. (1995): A guide to the birds of Mexico and Northern Central America. - Oxford University Press, Oxford.

[43] Ibáñez-Álamo, J. D., Rubio, E., Benedetti, Y., Morelli, F. (2017): Global loss of avian evolutionary uniqueness in urban areas. - Global Change Biology 23(8): 2990-2998. doi: 10.1111/gcb.13567.

[44] Ives, C. D., Lentini, P. E., Threlfall, C. G., Ikin, K., Shanahan, D. F., Garrard, G. E., Bekessy, S. A., Fuller, R. A., Mumaw, L., Rayner, L., Rowe, R., Valentine, L. E., Kendal, D. (2016): Cities are hotspots for threatened species. - Global Ecology and Biogeography 25(1): 117-126. doi: 10.1111/geb.12404.

[45] Jokimäki, J. (1999): Occurrence of breeding bird species in urban parks: Effects of parkstructure and broad-scale variables. - Urban Ecosystems 3(1): 21-34. doi: 10.1023/a:1009505418327.

[46] Kale, M., Dudhe, N., Ferrante, M., Ivanova, T., Kasambe, R., Trukhanova, I. S., Bhattacharya, P., Lövei, G. L. (2018): The effect of urbanization on the functional and scale-sensitive diversity of bird assemblages in Central India. - Journal of Tropical Ecology 34(6): 341-350. doi: 10.1017/s0266467418000317.

[47] Karamanoglu, K. (1976): Turkiye bitkileri (1 ${ }^{\text {st }}$ ed.). - Ankara Universitesi Eczacilik Fakultesi, Ankara.

[48] Keller, J. K., Richmond, M. E., Smith, C. R. (2003): An explanation of patterns of breeding bird species richness and density following clearcutting in northeastern USA 
forests. - Forest Ecology and Management 174(1-3): 541-564. doi: 10.1016/s03781127(02)00074-9.

[49] Khera, N., Mehta, V., Sabata, B. C. (2009): Interrelationship of birds and habitat features in urban greenspaces in Delhi, India. - Urban Forestry \& Urban Greening 8(3): 187-196. doi: 10.1016/j.ufug.2009.05.001.

[50] Kirchner, T. B. (1977): The effects of resource enrichment on the diversity of plants and arthropods in a shortgrass prairie. - Ecology 58(6): 1334-1344.

[51] Kirwan, G., Demirci, B., Welch, H., Boyla, K., Özen, M., Castell, P., Marlow, T. (2008): The birds of Turkey. - Christopher Helm, London.

[52] Kowarik, I., von der Lippe, M. (2018): Plant population success across urban ecosystems: A framework to inform biodiversity conservation in cities. - Journal of Applied Ecology 55(5): 2354-2361. doi: 10.1111/1365-2664.13144.

[53] Kramer, D. L., Bonenfant, M. (1997): Direction of predator approach and the decision to flee to a refuge. - Animal Behaviour 54(2): 289-295. doi: 10.1006/anbe.1996.0360.

[54] Lancaster, R. K., Rees, W. E. (1979): Bird communities and the structure of urban habitats. - Canadian Journal of Zoology 57(12): 2358-2368. doi: 10.1139/z79-307.

[55] Lepczyk, C., Warren, P. (2012): Urban bird ecology and conservation ( $1^{\text {st }}$ ed.). University of California Press, London.

[56] Lindenmayer, D. B., Laurance, W. F., Franklin, J. F., Likens, G. E., Banks, S. C., Blanchard, W., Gibbons, P., Ikin, K., Blair, D., McBurney, L., Manning, A. D., Stein, J. A. R. (2014): New policies for old trees: Averting a global crisis in a keystone ecological structure. - Conservation Letters 7(1): 61-69. doi: 10.1111/conl.12013.

[57] Livingston, M., Shaw, W. W., Harris, L. K. (2003): A model for assessing wildlife habitats in urban landscapes of eastern Pima County, Arizona (USA). - Landscape and Urban Planning 64(3): 131-144. doi: 10.1016/s0169-2046(02)00217-7.

[58] Macgregor-Fors, I., Schondube, J. E. (2011): Gray vs. green urbanization: Relative importance of urban features for urban bird communities. - Basic and Applied Ecology 12(4): 372-381. doi: 10.1016/j.baae.2011.04.003.

[59] Mamıkoglu, N. G. (2010): Turkiye'nin agaclari ve calilari ( $7^{\text {th }}$ ed.). - NTV Yayinlari, Istanbul.

[60] Manning, A. D., Fischer, J., Lindenmayer, D. B. (2006): Scattered trees are keystone structures - Implications for conservation. - Biological Conservation 132(3): 311-321. doi: 10.1016/j.biocon.2006.04.023.

[61] Mao, Q., Liao, C., Wu, Z., Guan, W., Yang, W., Tang, Y., Wu, G. (2019): Effects of land cover pattern along urban-rural gradient on bird diversity in wetlands. - Diversity 11(6): 86. doi: 10.3390/d11060086.

[62] Martín, J., López, P. (1995): Escape behaviour of juvenile Psammodromus algiruslizards: constraint of or compensation for limitations in body size? - Behaviour 132(3-4): 181192.

[63] Marzluff, J. M., Ewing, K. (2001): Restoration of fragmented landscapes for the conservation of birds: A general framework and specific recommendations for urbanizing landscapes. - Restoration Ecology 9(3): 280-292. doi: 10.1046/j.1526100x.2001.009003280.x.

[64] McCurdy, J. D. (2016): The effects of human development on avian diversity along an urban-rural gradient in Iowa City, Iowa. - Geography Master of Arts (MA), University of Iowa.

[65] McKinney, M. L. (2006): Urbanization as a major cause of biotic homogenization. Biological Conservation 127(3): 247-260. doi: 10.1016/j.biocon.2005.09.005.

[66] Meles, S. K., Bogale, B. A. (2018): Assessment of bird diversity and abundance from Waste Disposal Sites in and around Gubre Subcity, Wolkite Town, Southwestern Ethiopia. - International Journal of Waste Resources 8(4): 1000354. doi: 10.4172/22525211.1000354. 
[67] Mills, G. S., Dunning Jr., J. B., Bates, J. M. (1989): Effects of urbanization on breeding bird community structure in southwestern desert habitats. - The Condor 91(2): 416-428. doi: $10.2307 / 1368320$.

[68] Morrison, M. L., Marcot, B., Mannan, W. (1992): Wildlife-habitat relationships: Concepts and applications ( $1^{\text {st }}$ ed.). - University of Wisconsin Press, Madison.

[69] Moss, S., Martin, M. (2019): Urban aviary: A modern guide to city birds. - White Lion Publishing. London.

[70] Muñoz-Pedreros, A., González-Urrutia, M., Encina-Montoya, F., Norambuena, H. V. (2018): Effects of vegetation strata and human disturbance on bird diversity in green areas in a city in southern Chile. - Avian Research 9(1): 38. doi: 10.1186/s40657-0180130-9.

[71] Pacheco, R., Vasconcelos, H. L. (2007): Invertebrate conservation in urban areas: Ants in the Brazilian Cerrado. - Landscape and Urban Planning 81(3): 193-199. doi: 10.1016/j.landurbplan.2006.11.004.

[72] Palmer, G. C., Fitzsimons, J. A., Antos, M. J., White, J. G. (2008): Determinants of native avian richness in suburban remnant vegetation: Implications for conservation planning. Biological Conservation 141(9): 2329-2341. doi: 10.1016/j.biocon.2008.06.025.

[73] Rodewald, P. (2015): The birds of North America. - Retrieved March 2020, from https://birdsna.org.

[74] Rottenborn, S. C. (1999): Predicting the impacts of urbanization on riparian bird communities. - Biological Conservation 88(3): 289-299. doi: 10.1016/s00063207(98)00128-1.

[75] Sandström, U. G., Angelstam, P., Mikusiński, G. (2006): Ecological diversity of birds in relation to the structure of urban green space. - Landscape and Urban Planning 77(1-2): 39-53. doi: 10.1016/j.landurbplan.2005.01.004.

[76] Sewell, S. R., Catterall, C. P. (1998): Bushland modification and styles of urban development: their effects on birds in south-east Queensland. - Wildlife Research 25(1): 41-63. doi: https://doi.org/10.1071/WR96078.

[77] Shanahan, D. F., Miller, C., Possingham, H. P., Fuller, R. A. (2011): The influence of patch area and connectivity on avian communities in urban revegetation. - Biological Conservation 144(2): 722-729. doi: 10.1016/j.biocon.2010.10.014.

[78] Shochat, E., Lerman, S., Fernández-Juricic, E. (2010): Birds in urban ecosystems: population dynamics, community structure, biodiversity, and conservation. - In: Aitkenhead-Peterson, J., Volder, A. (eds.) Urban Ecosystem Ecology 55: 75-86., American Society of Agronomy, USA.

[79] Shwartz, A., Shirley, S., Kark, S. (2008): How do habitat variability and management regime shape the spatial heterogeneity of birds within a large Mediterranean urban park? - Landscape and Urban Planning 84(3-4): 219-229. doi: 10.1016/j.landurbplan.2007.08.003.

[80] Shwartz, A., Muratet, A., Simon, L., Julliard, R. (2013): Local and management variables outweigh landscape effects in enhancing the diversity of different taxa in a big metropolis. - Biological Conservation 157: 285-292. doi: https://doi.org/10.1016/j.biocon.2012.09.009.

[81] Stagoll, K., Lindenmayer, D. B., Knight, E., Fischer, J., Manning, A. D. (2012): Large trees are keystone structures in urban parks. - Conservation Letters 5(2): 115-122. doi: 10.1111/j.1755-263x.2011.00216.x.

[82] Strohbach, M. W., Haase, D., Kabisch, N. (2009): Birds and the city: urban biodiversity, land use, and socioeconomics. - Ecology and Society 14(2): 31.

[83] Suarez-Rubio, M., Aung, T., Lin, S. S., Shwe, N. M., Hlaing, N. M., Naing, K. M., Oo, T., Sein, M. M., Renner, S. C. (2016): Nonbreeding bird communities Along an urbanrural gradient of a tropical city in central Myanmar. - Tropical Conservation Science 9(4): 1-9. doi: 10.1177/1940082916675961. 
[84] Taylor, M. (2015): A naturalist's guide to the garden wildlife of Britain \& Northern Europe ( $1^{\text {st }}$ ed.). - John Beaufoy Publishing Ltd, Oxford.

[85] Temple, S. A., Wiens, J. A. (1989): Bird populations and environmental changes: Can birds be bio-indicators? - American Birds 43: 260-270.

[86] Tews, J., Brose, U., Grimm, V., Tielbörger, K., Wichmann, M. C., Schwager, M., Jeltsch, F. (2004): Animal species diversity driven by habitat heterogeneity/diversity: the importance of keystone structures. - Journal of Biogeography 31(1): 79-92. doi: 10.1046/j.0305-0270.2003.00994.x.

[87] TheCornellLab. (2017): All about birds. - Retrieved September 2019, from https://allaboutbirds.org.

[88] Thompson, P. S., Greenwood, J. J. D., Greenaway, K. (1993): Birds in European gardens in the winter and spring of 1988-89. - Bird Study 40(2): 120-134. doi: 10.1080/00063659309477137.

[89] Threlfall, C. G., Williams, N. S. G., Hahs, A. K., Livesley, S. J. (2016): Approaches to urban vegetation management and the impacts on urban bird and bat assemblages. Landscape and Urban Planning 153: 28-39. doi: 10.1016/j.landurbplan.2016.04.011.

[90] TRAKUS. (2020): Turkiye'nin kuslari. - Retrieved July 2020, from https://www.trakus.org/kods_bird/uye/?fsx=tur_arama.

[91] TUIK. (2020): Adrese dayali nufus kayit sistemi sonuclari. - Retrieved January 2020, from https://biruni.tuik.gov.tr/medas $/$ ?kn=95\&locale=tr.

[92] Vaccaro, A. S., Filloy, J., Bellocq, M. I. (2019): What land use better preserves taxonomic and functional diversity of birds in a grassland biome? - Avian Conservation and Ecology 14(1): 1. doi: 10.5751/ace-01293-140101.

[93] Van Heezik, Y., Smyth, A., Adams, A., Gordon, J. (2010): Do domestic cats impose an unsustainable harvest on urban bird populations? - Biological Conservation 143(1): 121130. doi: 10.1016/j.biocon.2009.09.013.

[94] Verner, J., Milne, K. A. (1989): Coping with sources of variability when monitoring population trends. - Annales Zoologici Fennici 26(3): 191-199.

[95] Villegas, M., Garitano-Zavala, Á. (2010): Bird community responses to different urban conditions in La Paz, Bolivia. - Urban Ecosystems 13(3): 375-391. doi: 10.1007/s11252010-0126-7.

[96] White, J. G., Antos, M. J., Fitzsimons, J. A., Palmer, G. C. (2005): Non-uniform bird assemblages in urban environments: The influence of streetscape vegetation. - Landscape and Urban Planning 71(2-4): 123-135. doi: 10.1016/j.landurbplan.2004.02.006.

[97] Wolff, P. J., Degregorio, B. A., Rodriguez-Cruz, V., Mulero-Oliveras, E., Sperry, J. H. (2018): Bird community assemblage and distribution in a tropical, urban ecosystem of Puerto Rico. - Tropical Conservation Science 11: 194008291875477. doi: $10.1177 / 1940082918754777$.

[98] Yang, G., Xu, J., Wang, Y., Wang, X., Pei, E., Yuan, X., Li, H., Ding, Y., Wang, Z. (2015): Evaluation of microhabitats for wild birds in a Shanghai urban area park. - Urban Forestry and Urban Greening 14(2): 246-254. doi: 10.1016/j.ufug.2015.02.005. 